Article Type: Research Paper

\title{
Result-based Management Implementation in Higher Education Institution: Determinants and Impact on Performance
}

\author{
Suryo Pratolo ${ }^{1 *}$, Arifin Hamsyah Mukti ${ }^{2}$, and Misbahul Anwar ${ }^{3}$
}

\begin{abstract}
:
Research aims: This research is purposed to examine human resource quality impact, organizational commitment and reward and punishment system to RbM implementation. More over, this research also examined RbM's impact to Higher Education Institution (HEI) Performance as well as RbM's role as variabel intervening.

Design/Methodology/Approach: Samples in this research were collected using convenience sampling method. This research uses survey method. Data in this research shall be primary data. Data collection method was executed by using questionnaire. Partial Least Square (PLS) technique was employed to test hypotheses proposed.
\end{abstract}

\section{AFFILIATION:}

12 Department of Accounting, Faculty of Economics and Business, Universitas Muhammadiyah Yogyakarta, Yogyakarta, Indonesia.

${ }^{3}$ Department of Management, Faculty of Economics and Business, Universitas Muhammadiyah Yogyakarta, Yogyakarta, Indonesia

\section{*CORRESPONDENCE:}

suryo@umy.ac.id

THIS ARTICLE IS AVAILABLE IN:

http://journal.umy.ac.id/index.php/ai

DOI: 10.18196/jai.2103166

\section{CITATION:}

Pratolo, S., Mukti, A. H., \& Anwar, M. (2020). Result-based Management and Public Organizational Performance: Determinant and It Impact to University. Journal of Accounting and Investment, 21(3), 580-601.

\section{ARTICLE HISTORY}

Received:

27 July 2020

Reviewed:

7 Aug 2020

Revised:

17 Aug 2020

Accepted:

17 Sept 2020

Research findings: This research shows Human Resource Quality, Organizational Commitment as well as reward and punishment system are proven having positive and significant impacts to RbM's implementation. Then RbM'S implementation is proven having impact to HEI Performance. Direct relationship to HEI Performance, Human Resource variable, Organisatonal Commitment, and reward and punishment system are not proven directly on HEI Performance, but specifically Human Resaource Quality, organizational commitment as well as reward and punishment system inderictly impact on HEI Performance via RbM implementation. It may be concluded that RbM implementation is much important to be realized then by increasing Human Resource Qualtiy, Organizatioinal Commitment as well as Reward and Punishment system are able to realize better HEI Performance.

Theoretical contribution/Originality: This research is purposed to confirm goal setting theory related to RbM implementation in study context in $\mathrm{HEl}$.

Practitioner/Policy implication: This research result may become an input for $\mathrm{HEI}$ management to increase it performance via RbM policy implementation.

Research limitation/Implication: This research may be executed in private $\mathrm{HEI}$ in eastern West Java.

Keywords: Higher Education Institution (HEI); Human Resource Quality; Organizational Commitment; Reward and Punishment System; Result based Management; Performance

\section{Introduction}

Higher Education Institution (HEI) performance becomes something that continuously efforted at this moment, which is demonstrated by efforts of Indonesia's government in executing accreditation and giving financial stimulant as well as competition in HEl ranking of all Indonesia. 
Bearing in mind HEl purpose which is much strategic for development of a nation, efforts to continuously increasing HEl quality in Indonesia by maximal organizational performance increasing is very crucial (Dill, 2009; Vnoučková, Urbancová, \& Smolová, 2018). But, in fact, HEI performance, especially private HEI (PTS) which it number bigger than state HEl in Indonesia, has not optimal yet, more over universities which operate in cities which are not big enough as eastern part of West Java: Tasikmalaya, Ciamis, Kuningan, Indramayu, and Cirebon. Said cities have pretty much universities. But, quality and performance of universities located in such regions has not good enough. Figure 1 shows summary of HEl quality located in said cities on 2020.
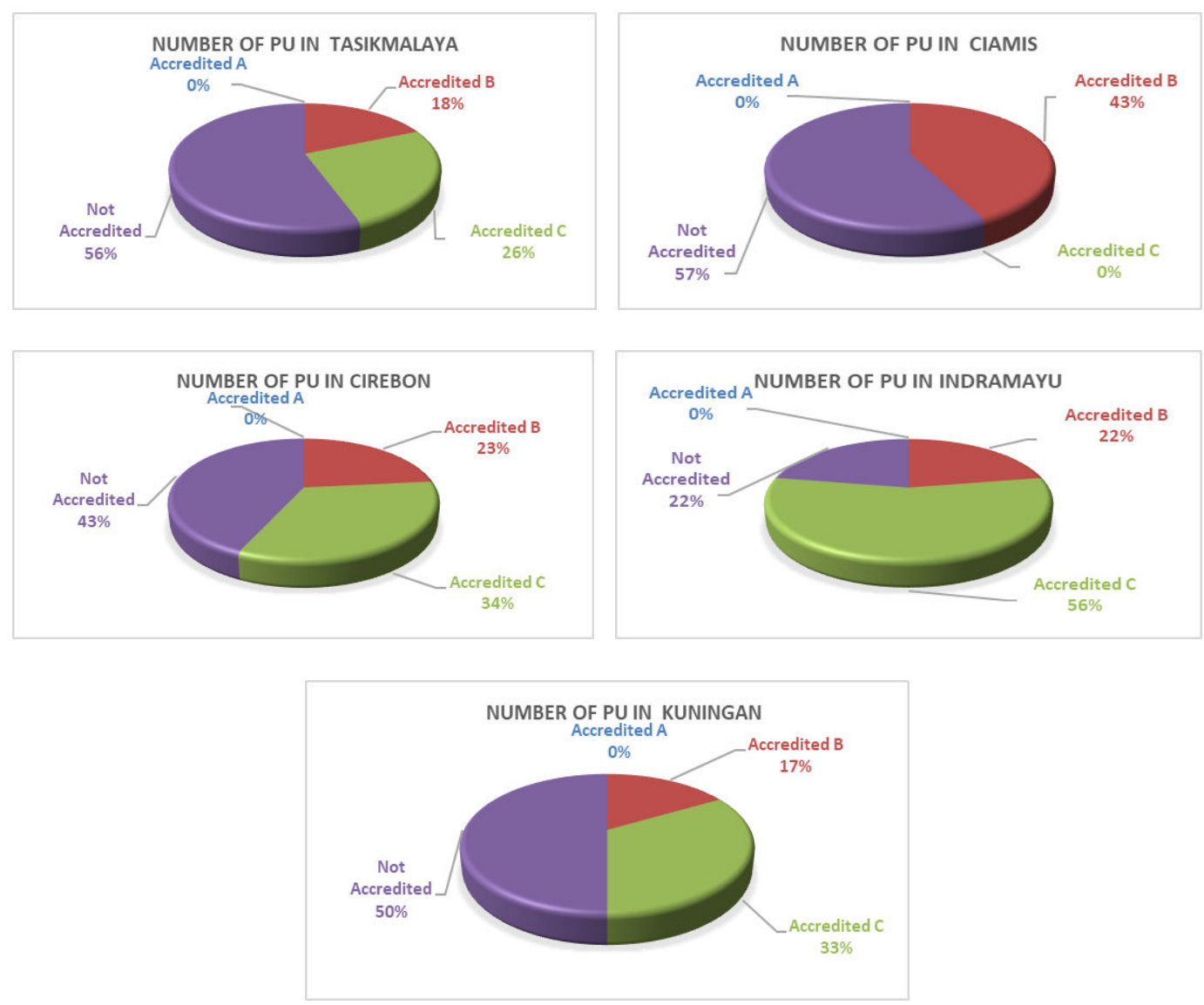

Note: Number of PU (Privte HEI) in Tasikmalaya 27, Ciamis 7, Cirebon 30, Indramayu 9, Kuningan 6

Figure 1 Accreditation of PU in Eastern Region of West Java Source: HEI National Accreditation Board (BAN-PT)

(https://www.banpt.or.id/direktori/institusi/searching in_institusi.php accessed on January, 5 2020)

From Figure 1 it can be concluded that generally universities in Eastern Region of West Java have performaces which not good enough. It is found that there is no accredited $A$ campus, most are accredited $C$, and lot which have not accredited yet. Pratolo, Sofyani and Anwar (2020) explained that accreditation shall be an indicator for HEl performance 
in Indonesia which campus performance shall be one of assessment standar factor. It means, that when quality of a campus has not good yet, it indicates that performance of such campus has not optimal yet. PTS's condition which is proxied by accreditation grade also shows how good implemented management is, as well as how far system aspect and personel aspect have been properly managed. One of good management system shall be Result-based Management (RbM) which all efforest are focused on maximal result achievement under basis of norms of Good Governance (Arif, Jubair \& Ahsan, 2015). In RbM, management functions consist of planning, organizing, actuating, and controlling are executed to be focused on achievement of result performance target (Kimiri, 2018). Resarch of Arif et al. (2015) revealed that RbM's frame work results better findings than at this moment's monitoring practice executed in public sectors, due to RbM's frame work clearly monitors project purpose directly which in line with long term purpose assessment. Meanwhile, Mutambatuwisi, Nyasha, Muchadenyika, and Faith (2016) stated that RbM is effective in increasing performance as demonstated customer care, ability to meet performance target and producing qualified product. From such two researches, it may be conluded that RbM implementation may hold organizational performance.

$\mathrm{RbM}$ it self already commenced be applied in some universities in Indoensia. But in it practice, RbM has not optimally applied in HEl entity environment. Some facts from research results show such condition. Research of Santosa (2014) demonstrated that HEI trategic plan has not been used as a reference in preparing a budget, there is no evaluation and calculation of income increasing and fund expenditure, too much budget revision, and budget achievement not meet the target. Further, research of Kimiri (2018) found that organizational culture and organizational resource affected RbM implementation. Research which executed by Sylvia (2015) explained that RbM shall be started by strategic planning process to identify planning priority which in line with purpuses.

Further, there are some researches which examine determinant from a management policy in an organization. Research of Sholihah and friends (2015) found that human resource may support success of implementation of performance based budget. This result in line with Dara and Basuki findings (2010) that human resource shall be crucial factor in adopting permormance standard and implementation of performance based budget in regional governmental institutions. Pratolo et al. (2020) in his research stated in order to succeed implementation of performance based assessment, shall be a consideration regarding on organizational competence and commitment in all organizational levels, in addition reward and punishment system also becomes fundamental part of PBB policy so it may run effectively. Research of Upping and Oliver (2012) demonstrated that to achieve a success in adopting new policy on financial accountancy system and management, qualified staff and continous support from organization are much required.

Until this day, research regarding on RbM especially in $\mathrm{HEl}$ either determinant issue or impact of $\mathrm{RbM}$ implementation it self remains so hard, so it remains a research gap. 
Explicitly this research is purposed to examine Rbm'S determinant and impact of RbM it self to HEl performance.

It required lot of supporting variables, include human resources quality, organizational commitment, as well as reward and punishment system. Qualified human resource is reflected by ability to work effectively and efficiently so may give optimal contribution to organizational performance, and one factor which affects the performance shall be human resource quality which consist of technical ability and mental behavior (Spenser \& Spenser, 1993). According to Robbins and Judge (2014) commitment of organization constitutes a condition which a person takes side on organization and it purposes, as well as intends to maintain member of such organization. So he has high commitment to an organization which believed able to increase good performance on an organization in a HEI. While according to Koencoro, AL Musadieq, and Susilo (2013) stated that in order to maintain and increase a performance, a company shall promptly prepare it self in managing profitable and professional management, one way by implementing reward and punishment system. So by existence of this reward and punishment system company's performance may be increased and company's purposes may be achieved in entirety because when organization provides with reward to it employees who work properly then such employess will have motivation to work better so it may increase employee's performance and organizations' performance it self.

This research has two contributions they are theoretical and practical. Theoretically this research confirms theory of purpose determination related to implementation of $\mathrm{RbM}$ in context of study in $\mathrm{HEl}$. Besides, this research gives new thing related to RbM discussion on HEl context by explaining RbM's determinant factors and RbM's roles in achievement efforts of HEl performance. Mean while, practically, this research result may become an input for HEI management to increase it performance by implementing RbM policy.

\section{Literature Review and Hypotheses Development}

According to Locke (1975), stated in case Goal Setting is realized by an individu or group in company, then will result high achievement level if completed with declaration of definite purpose. Locke and Latham (2013) explained that the absence of specific purpose and target may becomes ambiguity, confusion, and less of direction for subordinate. Therefore, the exixtence of concept of determination of definite purpose in formulation of performance assessment system may increase work motivation and organizational commitment in achieving purpose which finally will affect to performance increasing (Locke \& Latham, 2013). Further, there is relationship between goal setting theory and RbM system which by focued on all efforts upon maximal result under good norms by the existence of explication of organization's purpose, by contributed with qualified human resources, good organizational commitment as well as reward and punishment system which maximally applied then it hoped organization is able to increase in performance to be better. 
There were previous researches which tried to provide with empirical proves regarading on $\mathrm{RbM}$ and factors which support increasing performance of an organization. Research of Arif et al. (2015) stated that monitoring executed using RbM's frame work and KPI resulted better findings than this moment's monitoring practice which executed in public sector, due to RbM's frame work clearly monitors project purpose directly which in line with assessment of long term purpose and vision. Further, Try (2008) in his research found result that on 2004 in federal government of Canada has been succeed relatively in managing service result, handling problem of result assessment and increasing managerial flexibility. Besides, McKernan, Kennedy, and Aldred (2016) gave result that $\mathrm{RbM}$ has given significant study for interested party, so gave positive result in a thought which more clear regarding on better program's purpose, target, and design, as well as annual statement which more qualified. Research of Santosa (2014) which demonstrated that in one of HEl of Public Service (BLU) under ministry of religious affair implementation of the management there were facts $\mathrm{HEI}$ strategic plan has not been used as a reference in preparing budget, there were no calculation of income increasing and fund expenditure, too many budget revisions, budget achievemtn not met the target. While Darlina, Yunnizar, and Hodijah (2016) in her research found consistency level result between planning and budgeting remained low. It happened due to lack of knowledge belongs to sub office educational planning staff upon planning and budgeting process. Research executed by Gerhana, Rezti, and Wasis (2019) demonstrated that human resources quality, work professionalism and employee's commitment are able to support organization in increasing it performance in achieving purpose. While, Mas'ud, Jonathan, and Lau (2017) stated that by implementing reward and punishment system properly in an organization then such organization performance will be beter.

\section{Impact of Human Resoucres Quality to RbM}

Human resource constitutes system which each employee has function to achieve organization's purpose. The organization success depends on employment of efficient human resource based on behavior science. Widyantoro (2009) explained that significant factor which determines the success of RbM implementation shall be human resources. Bishop (2015) stated that the powerfull human resources shall be the significant factor in RbM establishment. According to Mulikita (2002), in order to make $\mathrm{RbM}$ effectively funcionted, Human Resource (HR) shall be adopted and executed professionally include staff recruitment, training, career management and compensation. Flint (2003) stated that staff recruitment, compensation and career management decision which not executed professionally based on achievement, and employee realizes that their efforts not meet their appreciation, there was almost no motivation between employees which will trigger and support superiority in their performance. According to Binnendijk (2001) providing with suitable training shall be effective way as success factor of RbM implementation which involving employee. Based on previous basic theory and research which has been elaborated, researcher advice hyphotesis as follows:

$\mathrm{H}_{1}$ :Human Resources Quality has positive significant impact to RbM. 


\section{Impact of Organizatiional Commitment on RbM}

Significant factors to support RbM's success covers the need to accept support in all organizations due to it success needs long term. Bansal, Irving, and Taylor (2004) defined commitment as a power binds individu to actions which have relevance with organizational purpose. According to Alrowwad, Almajali, Masa'deh, Obeidat, and Aqqad (2019), organizational commitment has significant influence on organizational effectivity this in line with stewardship theory, which manager tends loyal to his organization because he has good organizatioinal commitment which showed on his effort to try to reach their organizatioinal purpose by waives their interest. Cavalluzzo and Ittner (2004) found that organizational commitment from management plays significant role in developing organizational policy related to performance achievement effort. Individual or employee's loyalty may be found from commitment level to organization. Having strong organizational commitment may make an individu always try to reach organizational purpose by waiving individual purpose, always has positive thinking and always do the best for their organization so organizational purpose may be reached. Sofyani and Akbar (2013) had an opinion that commitment reflected in activity as allocating human resources, purpose, strategy for various plans which considered precious, therefore powerfull commitment will be much affects organization in policy implementation related to performance increasing. Organizational commitment makes an individu from leader to subordinate may work together properly and perform their job follows decided regulation shall be factors which influence the success or failure of RbM implementation.

$\boldsymbol{H}_{2}$ : Organizational commitment has significant positive impact on $\mathrm{RbM}$.

\section{Impact of Reward and Punishment System on RbM}

Advantage reward which may be perceived by employee shall be they may be motivated to support organization. When annual bonus which depends on performance considered fairly distributed, such bonus may satisfy employee's need upon otonomy and competence, and therefore strengthen otonom motivation, and it turn, performance. Antoni, Baeten, Perkins, Shaw, and Matti (2017) researched about relation between appreciation management and motivation which showed that reward related to motivation. This motivation further expected will rise support on organization in implementing RbM. According to Kadarisman (2012) reward for company, shall be: (1) recruit employee with high work ability level in company, (2) provide with stimulation so employee works under intent to reach high achievement, (3) bind employee to remain work for company. Punishment shall be the opposite of reward system, which reward shall be a form of positive motivation while Punishment shall be a form of negative motivation. Punishment shall be not fun or not expected consequences given by employer for specific behavior as determined. Firmansyah (2019) said three important functions of punishment which play main role in establishing expected behavior, includes: (1) limiting behavior so it will prevent repetation of unpredicted behaviour, (2) be education, (3) strengthen motivation to avoid unpredicted behavior. Research of 
Mas'ud et al. (2017) explained that reward and punishment system has positive impact to performance of a company. By existence of positive impact and supported by RbM system which oriented to result then organizational purpose will be achieved.

$H_{3}:$ Reward and Punishment System has significant positive impact on RbM.

\section{Impact of Human Resource Quality on HEI Performance}

Organizational Quality shall be multi-dimension construction covers lot of factors as influenced it, factors which influence quality includes individual factor, leadership factor, team factors. System factor, and contextual factor. Employee's quality and number of investigation in human resources shows positive relationship with organizatioinal development (Gossling \& Rutten, 2007; Santos-Rodrigues, Faria, Cranfield, \& Morais, 2010). Pratiwi and Himam (2014) defined performance as a behavior which related to achievement of purposes which may be verified by an organization. It purposed to create high work culture which an individu and team be responsible to continuously increase skill, process and reach target. Particularly, performance may be declared as estimation of employee individual purpose with organizational purpose only when employee supports organizational culture. It give a hope as stipulated and agreed regarding on role responsibility and accountability, skill and behavior. Spesifically, performance may be stated as estimation (Armstrong, 2006). Matutina (2001) said that human resource quality refers to knowledge, skill and abilities which it shall be fundamental thing required for a company in order to increase it performance.

$\boldsymbol{H}_{4}$ : Human Resources Quality has significant positive impact on HEI Performance.

\section{RbM Impact on HEl Performance}

RbM consititutes management under basis on achievement of result actually and maximally. Research of Arif et al. (2015) demonstrated that on public organization, project monitoring uses $\mathrm{RbM}$ approach may result better result and conclusion compared with traditional approach. By RbM approach project monitoring may be executed in line with long term purpose assessment. RbM provides with comprehension for personel regarding on what have to be achieved and have to be done, so it may focused on purpose achievement through deninite program and activity and may support performance report which more qualified and provide with proves and facts of stronger performance achievement (McKernan et al., 2016). From research result and description regarding on $\mathrm{RbM}^{\prime}$ s role aforesaid shows that RbM's superiority in supporting organizational performance shall be the existence of harmony between long term purpose and measurable program and activity based on definite performance indicator so program may be properly controlled and result performance report which more definite in issue of failure and success of executed program and activity. Try (2008) in a research found result that RbM in federal government of Canada relatively has been succeed in managing service result, handling result assessment issue and increasing 
managerial flexibility. Mutambatuwisi et al. (2016) stated that RbM is effective in increasing performance as showed by ability to meet target and producing qualified product.

$\boldsymbol{H}_{5}:$ RbM has significant positive impact on HEl Performance.

\section{Impact of Organizational Commitment on HEI Performance}

Involment and employee's empowerment shall be one element which most missinterpreted from approach of total quality and one element which most misinterpreted by haters. There are two basics to involve employee. First, increasing possibility of better decision, or escalation which more effective by holding wider thought to face situation - not only thought whatsoever but thought belongs to persons most close to said work. Second, promoting decision ownership by involving persons who have to apply it. To achieve maximal organizational quality, it required professional work climate. It shall be established by commitment, which consist of company's commitment to employee, and vise versa. Individu who is satisfy with his work tends meet his commitment of organizations, and therefore rises employee's loyalty to organization, which finally caused an employee has dependency and responsibility feeling to organization. Under various levels of commitment belongs to employee will direct to different organizational quality relationship result. Work commitment shall be psychological employee's bond in a form of very strong desire to remain be an employee of an organization as indicated by willingness to maximally use all power and effort for organizational interest. Employess's commitment depends on organizational support as felt also impacted on employee's behavior and satisfaction. Employee's emotional and psychological behavior to organization will create sense of belonging to organization, and, therefore, desire to develop organization will rise.

According to Ari (2011) stated that advantage from organizational commitment shall be: (1) Serious employee who shows high commitment to organization has much possibility to show high participation level in organization; (2) Having stronger desire to keep working in organization at this moment and may keep contributing to achieve purpose; and (3) Fully involved with work, due to work shall be main mechanism and line for individu to contribute on organizational purpose achievement.

Research executed by Djuwita, Soemantri, and Prima (2018) demonstrated that organizational commitment has positive and significant impact to organizational performance. Ndiwalana (2009) stated in case an individu has had commitment on a purpose, then it will influence such individual act and finally increase performance of such individu and organization. Yusfaningrum (2005) explained that commitment to organization which getting more higher than performance of individu as member of organization in managerial activity will get more increasing.

$\boldsymbol{H}_{6}$ : Organizational Commitment has significant positive impact on HEI Performance. 


\section{Impact of Reward and Punishment System on HEI Performance}

Social exchange theory sees any mutual relationship between beaviour and environment; when employee management system has not been applied optimally which there is any unfair procedure in promotion process, it has impact to employee's commitment moreover it is given with external reward. This study proved that social exchange basical principle shall be "distributive justice" rule which says that reward shall be equal with investment which not valid always; but more over procedural justice which perpetuates exchange relationship. Organization decides to use reward due to two reasons: 1) to control cost by only provide with truly valuable reward to employee, and 2) to obtain advantages from increasing of employee's behavior and manner. The using of reward option reflects that traditional approach which offers standard reward has not succeed control cost or increasing performance; these general reward ways tend to create bad result (Yusof, Yaacob, \& Rahman, 2018). Reward option is enable organization to provide with reward which adjusted with each individu, and become believed to help them competite to recruite and hold the best employee, also contributed on their next performance. Hauristical justice theory shows worker perception regarding on reward system justice will generalize their perception regarding on organization in entirety (Mignonac \& Nathalie, 2013). When organization acts fairly in urgent and dominate situasion, then individu will tend to assume that organization is generally fair. Due to the importance of reward for employee assessment of reward system justice much impact in establishing perception of entire organization. Example given, reward option shall contribute on general perception of procedural justice among workers; having reward option will direct to justice perception in reward system and evaluation of reward system will be generalized to organization in entirety (Tyler, 1987). Review literature executed by Alkhafaji, Talab, Flayyih, and Hussein (2018) demonstrated that generally paper which discuss relationship between management controlling system includes reward and punishment system demonstrated any positive and significant relationship on organizational performance.

\section{$\boldsymbol{H}_{7}:$ Reward and Punishment System has significant positive impact on HEI Performance.}

Based on above hypotheses developed then research model is showed in Figure 2.

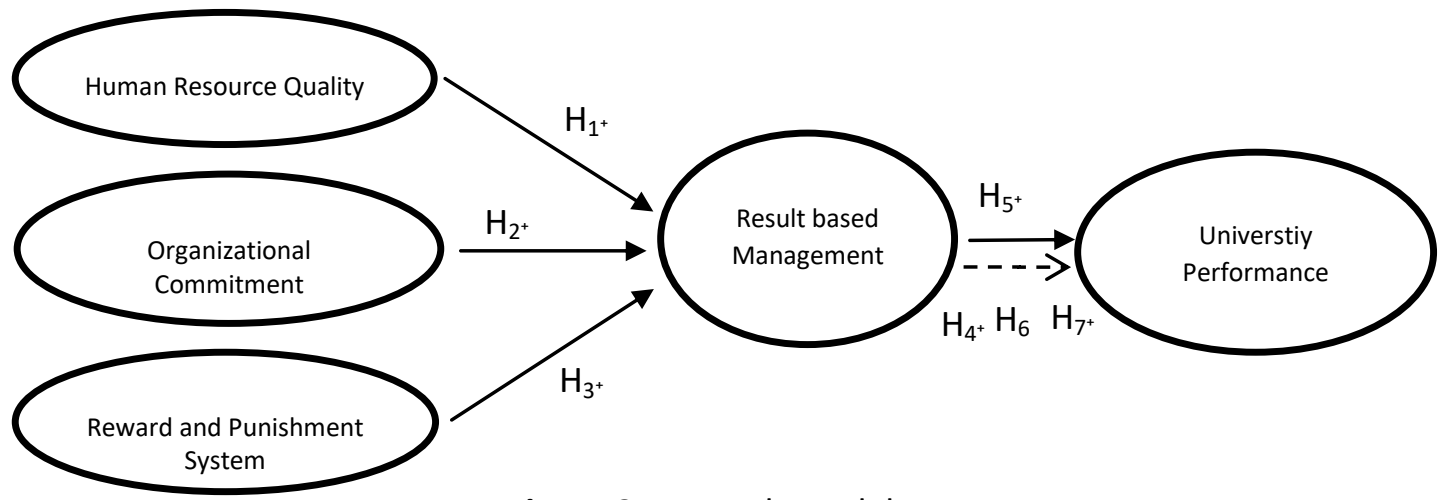

Figure 2 Research Model 


\section{Research Method}

\section{Population and Sample}

This research objects shall be private HEI in eastern of West Java, they are private HEI of Tasikmalaya, Ciamis, Cirebon, Kuningan, and Indramayu. Sample in this research collected using convenience sampling method which executed on event of Aptisi meeting of West Java in Muhammadiyah HEl of Tasikmalaya and activity of HEI Financial Management Workshop executed in HEl of Muhammadiyah Science of Kuningan. Respondent in this research shall be HEl leader and bureau head and financial division in each HEl. They were choosen as respondents under basis their knowledge related to implementation of RbM practice in their campus. Therefore by involving such parties then collected data may reflect real condition from RbM practice in researched campus. Data as used in this research shall be primary data, shall be data as collected directly from research object through respendent who has been selected previously. Data collecting technic executed by using questionnaire as adapted from some previous researches and modified pursuant to condition of this moment's research. Questionnaire has been formulated previously to be answered by respondents. Choosen method to execute this research shall be using survey method and directed group discussion.

\section{Operational Definition}

To examine hypothesis in this research, researched variables are classified into exogen variable and endogen variable. This research used three exogen variables they are Human Resource Quality, Organizational Commitment, Reward and Punishment System, and Result Based Management, and one endogen variable, shall be HEI Performance.

Human Resource Quality defines human resource quality as an employee's ability to place and perform their duties based on back ground of education, training, comprehend their duties, readiness to made a change in performance, able to predict any kind related to purpose and coordination, cooperate and avoid bad acts. Reward and Punishment System. Indicator used in this variable includes promotion, position, reward, compliment, and reward (Irawanti, 2016). Organizatioinal Commitment, based on Shore and Tetrick, (1991), organizational commitment complied employee's demeanor to organization, while felt organizational support indicates employess perception on organizational demeanor to their demeanor. Statement instrument regarding on budget participation variable pursuant to Mekta and Siswanto (2017). Organizational Commitment Variable consist of four indicators, shall be: continous commitment, the same of organizational purpose, the same of organizational norms and effective commitment. Result based management implementation Safitri (2019) under 8 statements as measured based on strategical plan determination, describes Strategic Plan in Work Plan, determine performance indicator, evaluation. HEI Performance adopts accreditation articles. 


\section{Data Analysis}

This Reserch uses PLS-SEM method as used to analize data and examine hypothesis. This method is able to perform examination of asessement model together with examine structural model (Chin, Marcolin, \& Newsted, 2003; Hair Jr, Sarstedt, Hopkins, \& Kuppelwieser, 2014). Two reasons for using PLS are Likert scale with non-parametric nature and number of possibility of multicolinierity element. Pursuant to (Akbar et al, 2012; Sofyani Riyadh, \& Fahlevi, 2020), PLS is considered appropriate for this research due to enable minimal data assumption and needs sample size which relative small (Chin et al, 2003). Pursuant to Hair, Black, Babin, Anderson, and Tatham (2010), minimum sample size for PLS analysis shall be "10 multiplies rule", means shall be bigger from 10 multiples of maximum number of outer or inner model attachment which shows to any invisible variable in model.

\section{Result and Discussion}

Result of examination and data analysis uses PLS application shows research data analysis result which may be described as follows.

\section{Covergent Validity Examination}

Pursuant to PLS analysis such covergent validity examination result shows that loading outer indicator from all constructions more than 0.4 (Hair, Black, Babin, Anderson, \& Tatham, 2006) so it may be conluded that covergen validity is met (see Table 1). 
Pratolo, Mukti, \& Anwar

Result-based Management and Public Organizational Performance: ...

Table 1 Covergent Validity Examination Result

\begin{tabular}{|c|c|c|c|c|c|c|c|}
\hline Code & Indicator & $\begin{array}{l}\text { HEI } \\
\text { performance }\end{array}$ & $\begin{array}{l}\text { Human Resource } \\
\text { Quality }\end{array}$ & $\begin{array}{l}\text { Organizational } \\
\text { Commitment }\end{array}$ & RbM & $\begin{array}{c}\text { Reward } \\
\text { and } \\
\text { Punishment }\end{array}$ & $\begin{array}{c}\text { Average } \\
\text { Variance } \\
\text { Extracted } \\
\text { (AVE) }\end{array}$ \\
\hline HEP5 & Percentage of student who graduate on time & 0.707 & & & & & \multirow[t]{5}{*}{0.528} \\
\hline HEP6 & Percentage of suitability of work field and graduation study program & 0.709 & & & & & \\
\hline HEP7 & Average of interval term graduate obtain a work & 0.738 & & & & & \\
\hline HEP9 & $\begin{array}{l}\text { Number of research made by permanent lecturer pursuant to his study } \\
\text { program within three years }\end{array}$ & 0.726 & & & & & \\
\hline HEP10 & $\begin{array}{l}\text { Percentage of student involvement who will take final project in } \\
\text { lecturer's research }\end{array}$ & 0.753 & & & & & \\
\hline HR2 & Having knowledge which support work & & 0.684 & & & & \multirow[t]{6}{*}{0.528} \\
\hline HR3 & Able to comprehend rule related to work & & 0.738 & & & & \\
\hline HR7 & Able to determine and manage work priority & & 0.692 & & & & \\
\hline HR9 & Able to execute duty under efficient time efisien & & 0.756 & & & & \\
\hline HR10 & Give the best service to work & & 0.813 & & & & \\
\hline HR11 & Having good work spirit & & 0.666 & & & & \\
\hline OC1 & Feel happy to dedicate of this HEI & & & 0.851 & & & \multirow[t]{8}{*}{0.512} \\
\hline OC3 & High norms as followed by HEI & & & 0.742 & & & \\
\hline OC5 & Feel proud becomes part of organization & & & 0.776 & & & \\
\hline OC6 & Work hard to develop HEI & & & 0.661 & & & \\
\hline OC7 & Will not leave HEI due to having high responsibility & & & 0.790 & & & \\
\hline OC8 & Not right to leave HEl even it much profitable & & & 0.573 & & & \\
\hline OC9 & Sign written commitment to reach organizatiional purpose & & & 0.625 & & & \\
\hline OC10 & Performance target system whichl will be reached & & & 0.665 & & & \\
\hline RbM1 & Prepare result performance target quantitatively. & & & & 0.795 & & \multirow[t]{6}{*}{0.601} \\
\hline $\mathrm{RbM} 2$ & Before prepare a budget it is determined fund plafond for each work unit & & & & 0.745 & & \\
\hline RbM4 & $\begin{array}{l}\text { This year budget, it number based on realization of the previous year } \\
\text { completed with inflation adjustment }\end{array}$ & & & & 0.565 & & \\
\hline RbM5 & Prepare budget based on quantitative result target & & & & 0.828 & & \\
\hline RbM6 & Having list of activity code & & & & 0.734 & & \\
\hline RbM7 & Having price standar document & & & & 0.759 & & \\
\hline
\end{tabular}


Pratolo, Mukti, \& Anwar

Result-based Management and Public Organizational Performance: ...

Table 1 Covergent Validity Examination Result (cont.)

\begin{tabular}{|c|c|c|c|c|c|c|c|}
\hline Code & Indicator & $\begin{array}{c}\text { HEI } \\
\text { performance }\end{array}$ & $\begin{array}{l}\text { Human } \\
\text { Resource } \\
\text { Quality }\end{array}$ & $\begin{array}{l}\text { Organizational } \\
\text { Commitment }\end{array}$ & $\mathrm{RbM}$ & $\begin{array}{l}\text { Reward and } \\
\text { Punishment }\end{array}$ & $\begin{array}{l}\text { Average Variance } \\
\text { Extracted (AVE) }\end{array}$ \\
\hline $\mathrm{RbM8}$ & Executed continuation budget evaluatiion of work unit & & & & 0.861 & & \\
\hline $\mathrm{RbM9}$ & Financial evaluation of result performance achievement & & & & 0.851 & & \multirow{6}{*}{0.723} \\
\hline RbM10 & Non Financial evaluation of result performance achievement & & & & 0.795 & & \\
\hline RP1 & Salary as I received from HEI based on my achievement performance & & & & & 0.625 & \\
\hline RP4 & HEl gives First Warning (SP 1) to employee who has no performance & & & & & 0.930 & \\
\hline RP5 & $\begin{array}{l}\text { HEl gives Second Warning (SP 2) to employee who has no performance after } \\
\text { given with First Warning }\end{array}$ & & & & & 0.935 & \\
\hline RP6 & $\begin{array}{l}\text { HEl take futher act to employee who has been given with Second Warning } \\
\text { remain has no performance in form of suspension/termination }\end{array}$ & & & & & 0.872 & \\
\hline
\end{tabular}

Result of Table 1 which shows that AVE score more than 0,5 (Fornell \& Lacker, 1981) also support examination condition so covergent validity examination is met.

Table 2 Discriminant Validity Examination Result

\begin{tabular}{lcccc}
\hline \multicolumn{1}{c}{ Indikator } & HEI performance & Human Resource Quality & Organizational Commitment & Result-Based Management \\
\hline HEI performance & 0.727 & & & \\
Human Resource Quality & 0.065 & 0.727 & 0.716 & \\
Organizational Commitment & 0.253 & 0.209 & 0.310 & 0.775 \\
Result-Based Management & 0.379 & 0.394 & 0.104 & 0.262 \\
Reward and Punishment & 0.109 & 0.047 & 0.850 & \\
\hline
\end{tabular}




\section{Discriminant Validity Examination Result}

Discriminant Validity Examination is shown by result of cross loading analysis 3. Such PLS result shows that load item score on it own construction is higher than other construction (Gefen \& Straub, 2005), means assumption of discriminant validity has been met.

\section{Reliability Examination Result}

From Table 3, PLS result shows that Cronbach Alpha from all constructs more than 0,6 (Chin et al., 2003) and Composite Reliability is higher than 0,5 (Fornell \& Larcker, 1981).

Table 3 Reliability Examination Result

\begin{tabular}{lcccc}
\hline \multicolumn{1}{c}{ Indikator } & $\begin{array}{c}\text { Cronbach's } \\
\text { Alpha }\end{array}$ & $\begin{array}{c}\text { Composite } \\
\text { Reliability }\end{array}$ & $\begin{array}{c}\text { Loading } \\
\text { Range }\end{array}$ & Conslusion \\
\hline HEl performance & 0.781 & 0.848 & $0.707-0.753$ & Reliabel \\
Human Resource Quality & 0.821 & 0.870 & $0.666-0.813$ & Reliabel \\
Organizational Commitment & 0.867 & 0.892 & $0.573-0.851$ & Reliabel \\
Result-Based Management & 0.915 & 0.930 & $0.565-0.861$ & Reliabel \\
Reward and Punishment & 0.865 & 0.911 & $0.625-0.935$ & Reliabel \\
\hline
\end{tabular}

From such construct quality analysis result it may be concluded that all construct variablea in this research have met criteria of covergent validity, discriminant and reliability, so may be continued to the next examination shall be hypothesis examination. Figure 3 shows the algoritm of PLS result in this research.

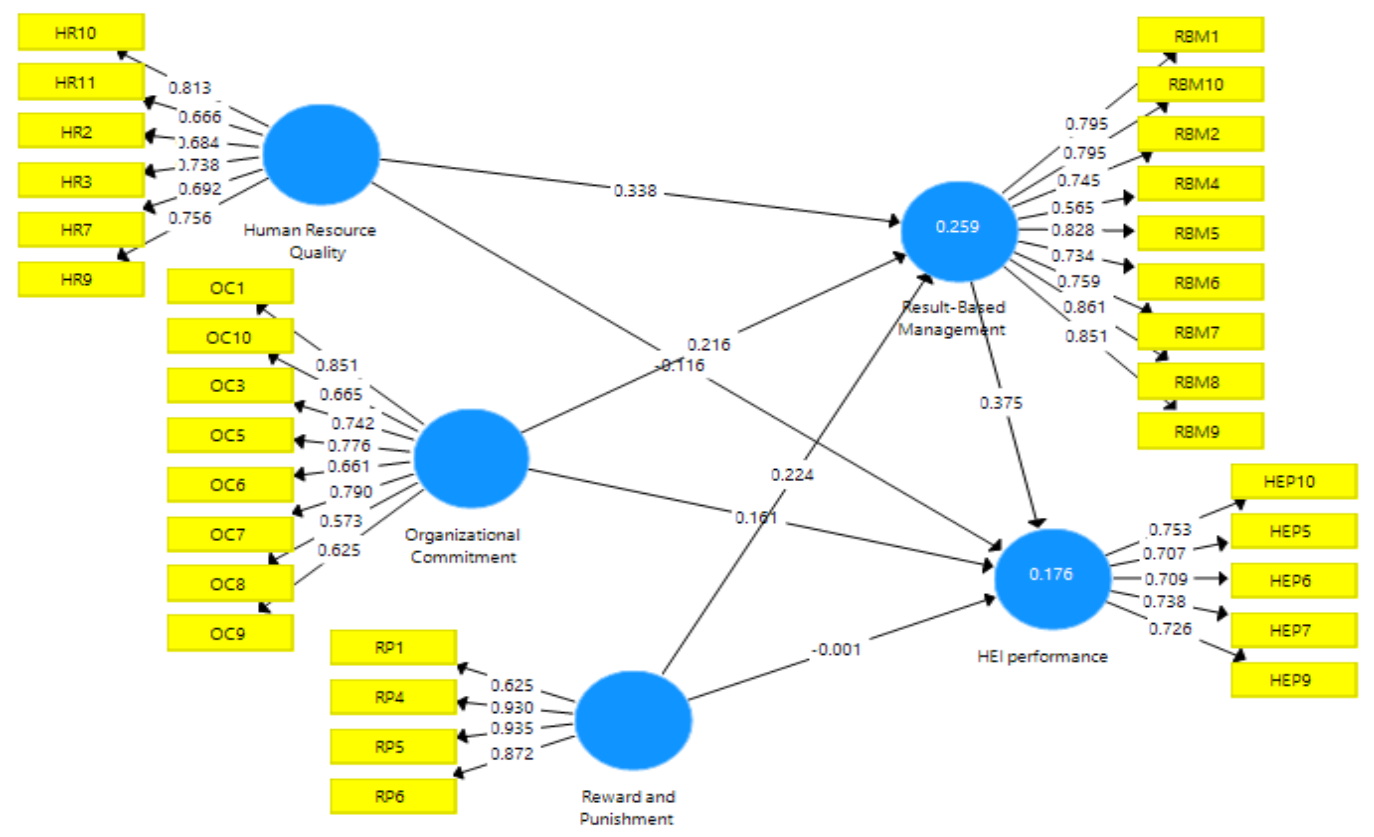

Figure 3 Result of algoritm PLS 


\section{Result of Hypotheses Examination}

Result of hypotheis examination is shown on Table 4. Hypothesis is supported if original sample direction same with hypothesis prediction direction, and score of $\mathrm{T}$ statistic is higher than 1.96 (alpha 0.05) or 2.58 (alpha 0.001).

Table 4 Result of Hypotheses Examination

\begin{tabular}{|c|c|c|c|c|}
\hline Hypothesis & & Coefficient & P Value & Conclusion \\
\hline $\begin{array}{l}\text { Human Resource } \\
\text { Quality -> Result-Based } \\
\text { Management }\end{array}$ & $\mathrm{H} 1$ & 0.338 & $0.000^{*}$ & Supported \\
\hline $\begin{array}{l}\text { Organizational } \\
\text { Commitment -> Result- } \\
\text { Based Management }\end{array}$ & $\mathrm{H} 2$ & 0.214 & $0.018 * *$ & Supported \\
\hline $\begin{array}{l}\text { Reward and } \\
\text { Punishment }->\text { Result- } \\
\text { Based Management }\end{array}$ & $\mathrm{H} 3$ & 0.224 & $0.012 * *$ & Supported \\
\hline $\begin{array}{l}\text { Human Resource } \\
\text { Quality -> HEI } \\
\text { performance }\end{array}$ & $\mathrm{H} 4$ & -0.124 & 0.215 & Not Supported \\
\hline $\begin{array}{l}\text { Result-Based } \\
\text { Management -> HEI } \\
\text { performance }\end{array}$ & H5 & 0.369 & $0.001^{*}$ & Supported \\
\hline $\begin{array}{l}\text { Organizational } \\
\text { Commitment -> HEI } \\
\text { performance }\end{array}$ & $\mathrm{H} 6$ & 0.171 & 0.202 & Not Supported \\
\hline $\begin{array}{l}\text { Reward and } \\
\text { Punishment }->\text { HEI } \\
\text { performance }\end{array}$ & $\mathrm{H} 7$ & -0.001 & 0.991 & Not Supported \\
\hline
\end{tabular}

Pursuant to such table it is known that examination result upon human resource, organizational commitment as well as reward and punishment system shows that it has positive impact to RbM under score of $t$ statistic $4.304 ; 2.376$; and 2.535 , so hypothesis 1,2 , and 3 are supported. Further, hypothesis 5 which states that RbM system has positive impact to HEI performance is accepted under socre of t statistic 3.316. While hypothesis 4.6 and 7 are not supported which state human resource, organizational commitment, and reward and punishment system not directly impact to HEI performance under score of $t$ statistic of $1.240 ; 1.277$; and 0.011 . Specifically indirect impact may be seen in Table 5 .

Table 5 Result of Hypotheis Examination Specifically Indirect Effect

\begin{tabular}{lcccccc}
\hline \multicolumn{1}{c}{ Hypothesis } & $\begin{array}{c}\text { Original } \\
\text { Sample }\end{array}$ & $\begin{array}{c}\text { Sample } \\
\text { Mean }\end{array}$ & $\begin{array}{c}\text { Standard } \\
\text { Deviation }\end{array}$ & T Statistic & P Value & Conclusion \\
\hline $\begin{array}{l}\text { Human Resource } \\
\text { Quality -> Result- } \\
\text { Based }\end{array}$ & 0.125 & 0.127 & 0.045 & 2.785 & $0.006^{*}$ & Supported \\
$\begin{array}{l}\text { Management -> } \\
\text { HEl performance }\end{array}$ & & & & & & \\
$\begin{array}{l}\text { Organizational } \\
\text { Commitment -> } \\
\text { Result-Based }\end{array}$ & 0.079 & 0.088 & 0.047 & 1.698 & $0.090^{* *}$ & Marginally \\
& & & & & & Supported \\
\hline
\end{tabular}




\begin{tabular}{|c|c|c|c|c|c|c|}
\hline $\begin{array}{l}\text { Management -> } \\
\text { HEI performance }\end{array}$ & & & & & & \\
\hline $\begin{array}{l}\text { Reward and } \\
\text { Punishment -> } \\
\text { Result-Based } \\
\text { Management -> } \\
\text { HEI performance }\end{array}$ & 0.083 & 0.085 & 0.044 & 1.898 & $0.058 * *$ & $\begin{array}{l}\text { Marginally } \\
\text { Supported }\end{array}$ \\
\hline
\end{tabular}

Based on such Table 5 shows that only human resource hypothesis effects to HEI performance through result - based- management as received under $p$ value score 0.006 lower than 0.01 while other two hyphotesises marginally supported due to value $\mathrm{p}$ score are 0.090 and 0.058 which lower than 0.10 . Figure 4 shows the result of PLS Path.

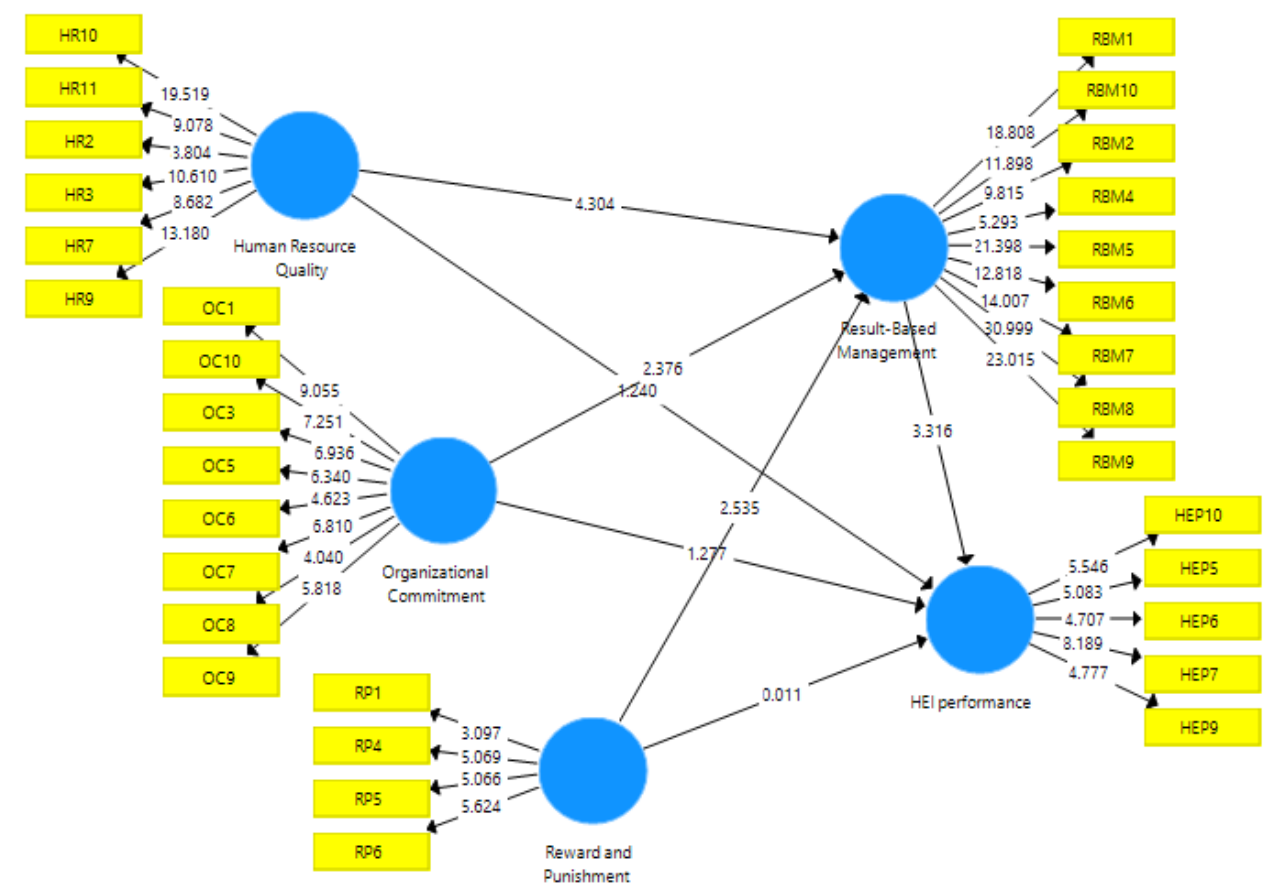

Figure 4 Result of Path Test Results

This research found that human resource quality positively effects to RbM. In line with Kimiri (2018) who suggest that human resource quality shall be directed to monitoring and evaluation which become main components in RbM implementation. Besides, organization shall ensure that all staff, senior manager and general staff have skill and expertise required to support RbM implementation. Further, this research found that organizational commitment positively effect RbM. Cavalluzzo and Ittner (2004) Stated that organizational commitment from management has significant role in developing organizational policy related to effort of performance achievement. So it may be concluded that commitment to organization which made by each member then it may support $\mathrm{HEl}$ to also implement $\mathrm{RbM}$ sistem properly. So the same as reward and 
punishment system which positively effect RbM. Under such result then by existence of reward and punishment system which properly executed then it will support realization of RbM implementation it self due to each member of organization will be motivated in working under RbM which oriented to result will definite employee in working to reach their performance target (Mas'ud et al., 2017).

This research also found that RbM positively effect HEI performance. In line with Arif et al. (2015); Mutambatuwisi et al. (2016), that this research drive so that RbM implementation shall be promptly executed due to RbM which focuses on result then $\mathrm{HEI}$ purpose will be achieved and by achieved such result performance of an $\mathrm{HEI}$ will be better. More over, this research alo confirm goal setting theory (Locke \& Latham, 2013) that $\mathrm{RbM}$ practice will clarify organizational purpose and much increase human resource quality, organizational commitment and reward and punishment system related to achieving organization purpose which it effect will increase HEI performance. But, this research remains obtained result which not support proposed hypothesis, which stated that human resource quality, organizational commitment as well as reward and punishment system not effect to HEI performance.

Specifically this research found something new which $\mathrm{RbM}$ is supported as intervening variable related to human resource quality to HEI performance. Under this result shows that human resource quality able to increase HEl performance through RbM system which properly applied. Besides, in other context RbM marginally supported in relation with organizational commitment as well as reward and punishment system to HEI performance. So it may be concluded that from such three results, good RbM implementation will remain support and provide with positive effect to increasing of HEI performance.

Condition of HEl performance in Indoensia especially in eastern region of West Java has not as expected either result of this research or seen based on accreditation score from BAN-PT. This performance condition which still not meet expectation certainly if be compared with $\mathrm{HEl}$ in world level remain can not be compared. In other issue law of national educational system, it is expected that $\mathrm{HEl}$ is able to create generation who will continue this nation who be superior and having character. Such fact makes management become important factor. To create awesome performance, it is also required awesome management system. RbM management system constitutes alternative manement system which theoretically if optimally executed will be able to support organization performance maximally. Fact, from research result implementation of $\mathrm{RbM}$ principles still low then this low RbM condition it is normal if makes $\mathrm{HEI}$ performance also becomes low.

Based on result research and there are also a phenomenon in such big $\mathrm{HEI}$, this research result support RbM position to be promptly implemented in $\mathrm{HEI}$, due to the absence of direct relationship between research components and $\mathrm{HEl}$ performance and there is any positive relationship to RbM system, under proper RbM implementation in $\mathrm{HEl}$ and supported with human resource quality, commitment to organization as well as reward 
and punishment system which also good, then it is believed that HEl is able to increase it performance to be better.

\section{Conclusion}

This research is purposed to examine effect of human resource quality, organizational commitment and reward and punishment system to RbM implementation. Besides, this research also examined $\mathrm{RbM}$ effect to $\mathrm{HEI}$ performance as well as RbM role as intervening variable. This research executed in PTS/private HEl in eastern region of West Java. This research result succinctly found that RbM mediates relationship human resource quality, organizational commitment as well as reward and punishment system to HEI performance. In other words, such three components they are human resource quality, organizational commitment as well as reward and punishment system will siginificantly effect to HEl performance if accompanied with RbM implementation. This research provide with contribution to development of science, especially related to empirical examination regarding on $\mathrm{RbM}$ role as intervening variable.

Separated from it positive implication, this research also has some limitedness. First, this research has no storng generalization power due to only executed in private universities in West Java. It is recommended that for the next research to expand research object so result which will be obtained later will be better. More over, study to phenomenon in this HEI need to be increased to find out deeper regarding on what happened in the field. The further research is suggested to use other approach as quantitative approach so research to research phenomenon will be executed in detail and obtained result will be more meaningfull.

\section{References}

Akbar, R., Pilcher, R. \& Perrin, B. (2012). Performance measurement in Indonesia: the case of local government. Pacific Accounting Review, 24(3), 262-291. https://doi.org/10.1108/01140581211283878

Alkhafaji, A., Talab, H. R., Flayyih, H. H., \& Hussein, N. A. (2018). The Impact Of Management Control Systems (Mcs) On Organizations Performance A Literature Review. Journal of Economics and Administrative Sciences, 24(105), 1-20. https://doi.org/10.33095/jeas.v24i105.67

Alrowwad, A., Almajali, D. A., Masa'deh, R., Obeidat, B., \& Aqqad, N. (2019). The Role of Organizational Commitment in Enhancing Organizational Effectiveness. 33rd Ibima Conference: Granada, Spain. Retrieved from https://ibima.org/accepted-paper/therole-of-organizational-commitment-in-enhancing-organizational-effectiveness/

Antoni, C. H., Baeten, X., Perkins, S. J., Shaw, J. D., \& Matti, V. (2017). Reward Management: Linking Employee Motivation and Organizational Performance. Journal of Personnel Psychology, 16, 57-60. https://doi.org/10.1027/1866-5888/a000187

Ari, J. (2011). Komitmen Organisasi. Retrieved from http://juniarari.blogspot.com/2011/11/komitmen-organisasi.html\%20(29 
Arif, M., Jubair, M., \& Ahsan, A.. (2015). Use of Result Based Management (RBM) Framework for Monitoring Projects of Public Sector in Pakistan - A Case Study. International Journal of Inovation, Management and Technology, 6(2), 130-135. https://doi.org/10.7763/ijimt.2015.v6.589

Armstrong, M. (2006). A Handbook of Human Resource Management Practice. 10th Edition, Kogan Page Publishing, London.

Bansal, HS, Irving, PG, \& Taylor, SF. (2004). Model tiga komponen pelanggan ke penyedia layanan. Jurnal Akademi Ilmu Pemasaran, 32(3), 234-250. https://doi.org/10.1177/0092070304263332

Binnendijk, A. (2001). Results Based Management in the Development Co-operation Agencies: A Review of Experience: Executive Summary. Development Assistance Committee (DAC). Retrieved from https://www.oecd.org/dac/evaluation/dcdndep/31950852.pdf

Bishop, J. (2015). Psychological \& Social Implications Surrounding Internet \& Gaming Addiction. US: IGI Global

Cavalluzzo, K.S., \& Ittner, C.D. (2004). Implementing performance measurement innovations: evidence from government. Accounting, Organizations and Society, 29(3-4), 243-267. https://doi.org/10.1016/S0361-3682(03)00013-8

Chin, W. W., Marcolin, B. L., \& Newsted, P. R. (2003). A Partial Least Squares Latent Variable Modeling Approach for Measuring Interaction Effects: Results from a Monte Carlo Simulation Study and an Electronic-Mail Emotion/Adoption Study. Information Systems Research, 14(2), 189-217. https://doi.org/10.1287/isre.14.2.189.16018

Dara, A., \& Basuki, H. (2010). Pengaruh Faktor-Faktor Rasional, Politik, dan Kultur Organisasi terhadap Pengadopsian Ukuran Kinerja dan Pengimplementasian Anggaran Berbasis Kinerja Instansi Pemerintah Daerah Lingkup Provinsi Maluku Utara. Tesis. Program Pascasarjana Universitas Gadjah Mada Yogyakarta. Retrieved from http://etd.repository.ugm.ac.id/home/detail pencarian/46343

Darlina, M., Yannizar, Y., \& Hodijah, S. (2016). Analisis Perencanaan dan Penganggaran Pada Dinas Pendidikan Provinsi Jambi. Jumal Perspektif Pembiayaan dan Pembangunan Daerah, 3(4), 257-268. https://doi.org/10.22437/ppd.v3i4.3527

Dill, D. D. (2009). Convergence and diversity: The role and influence of university rankings University Rankings, Diversity, and the New Landscape of Higher Education, 97-116. https://doi.org/10.1163/9789087908164008

Djuwita, R., Soemantri, R., \& Prima, G. K. (2018). The Influence of Organizational Commitment, Implementation of Accounting Information System and Workplace Environment to The Performance of Work Unit. Journal of Accounting Auditing and Business. 1(1), 81-95. https://doi.org/10.24198/jaab.v1i1.15657

Firmansyah, D. (2019). Peran Hukuman Edukatif dalam Membentuk Self Management Siswa (Studi Kasus di Madrasah Diniyah Mambaul Hisan Kadipaten Babadan Ponorogo). Skripsi. Institut Agama Islam Negeri Ponorogo.

Flint, M. (2003) Easier said than done: A review of results based management in multilateral development institutions. Herefordshire: Michael Flint \& Partners

Fornell, C., \& Larcker. D. F. (1981). Evaluating Structural Equation Models with Unobservable Variable and Measurement Error. Journal of Marketing Research, 18(1), 3950. https://doi.org/10.2307/3151312

Gefen, D., \& Straub, D. (2005). A Practical Guide to Factorial Validity Using PLS-Graph: Tutorial and Annotated Example. Communications of the Association for Information Systems, 16, 91-109. https://doi.org/10.17705/1cais.01605

Gerhana, W., Rezti, \& Wasis. 2019. Pengaruh Kualitas Sumber Daya Manusia dan Profesionalisme terhadap Kinerja Karyawan dengan Komitmen Organisasi sebagai 
Variabel Intervening (Studi Kasus pada Karyawan Dinas Pendidikan Hulu Sungai Selatan). Jurnal Riset Inspirasi Manajemen dan Kewirausahaan. 3(1), 49-57. https://doi.org/10.35130/irimk.v3i1.50

Gossling, T., \& Rutten, R. (2007). Innovation in Regions. European Planning Studies. 15(2), 253-270. https://doi.org/10.1080/09654310601078788

Hair, J. F., Black, W. C., Babin, B. J., Anderson, R. E., \& Tatham, R. L. (2006). Multivariate data analysis 6 th Edition. Upper Saddle River. NJ: Pearson Prentice Hall.

Hair, J. F., Black, W. C., Babin, B. J., Anderson, R. E., \& Tatham, R. L. (2010). Multivariate data analysis. 7th Edition. Upper Saddle River. NJ: Pearson Prentice Hall.

Hair, J. F., Jr, Sarstedt, M., Hopkins, L., \& Kuppelwieser, V. (2014). Partial least squares structural equation modeling (PLS-SEM) an emerging tool in business research. European Business Review, 26(2), 106-121. https://doi.org/10.1108/EBR-10-2013-0128

Irawanti, A. (2016). Pengaruh Pemberian Reward dan Punishment terhadap Kinerja Karyawan (Studi Kasus pada BMT Lima Satu Sejahtera Jepara). Skripsi. Purwokerto: Universitas Muhammadiyah Purwokerto.

Kadarisman, M. (2012). Manajemen Kompensasi. Edisi ke-1. Jakarta: PT. Raja Grafindo Persada

Kimiri, K. K. (2018). Factors Influencing the Implementation of Result Based Management in the United Nations Agencies in Nairobi. Thesis. Chandaria School of Business. Retrieved from http://erepo.usiu.ac.ke/11732/3887

Koencoro, G., AL Musadieq, M., Susilo, H. (2013). Pengaruh Reward dan Punishment terhadap Kinerja. Jurnal Administrasi Bisnis, 5(2), 1-8. Retrieved from http://administrasibisnis.studentjournal.ub.ac.id/index.php/jab/article/view/236

Locke \& G. P. Latham (2013). New developments in goal setting and task.performance. Routledge/Taylor \& Francis Group.

Locke, E. (1975). Personnel attitudes and motivation. Annual Review of Psychology, 26(1), 457480. https://doi.org/10.1146/annurev.ps.26.020175.002325

Mas'ud, R., Jonathan, R., \& Lau, E. (2017). Pengaruh Reward dan Punishment Terhadap Kinerja Pegawai di Dinas Pendidikan dan Kebudayaan Kabupaten Kutai Timur. Jurnal Ekonomia. 6(1), 147-153. Retrieved from http://ejurnal.untagsmd.ac.id/index.php/EKM/article/view/2603

Matutina. (2001). Manajemen Sumber Daya Manusia, Cetakan Kedua. Jakarta: Gramedia Widia Sarana Indonesia.

McKernan, E. Kennedy, K., \& Aldred, A. (2016). Adopting results based management in the non-profit sector: Trócaire's experience. Project Management Research and Practice. 3 (JulyDecember). 1-20, https://doi.org/10.5130/pmrp.v3i0.5122

Mekta, H. Q., \& Siswanto. (2017). Pengaruh Kepuasan Kerja Dan Komitmen Organisasi Terhadap Kinerja Karyawan PT. Indra Kelana Yogyakarta. Jurnal Profita: Kajian Ilmu Akuntansi, 5(2), 1-20. Retrieved from http://iournal.student.uny.ac.id/ojs/index.php/profita/article/view/9702/0

Mignonac, K., \& Nathalie, R. 2013. 'No Strings Attached?': How Attribution of Disinterested Support Affects Employee Retention. Human Resource Management Journal. 23(1), 72-90. https://doi.org/10.1111/j.1748-8583.2012.00195.x

Mulikita, N. (2008). Applying results based management (RBM) strategies in African public administration: challenges and opportunities. African Journal of Public Administration and Management, 19, 9-19. Retrieved from https://www.africabib.org/rec.php?RID $=$ Q00046657

Mutambatuwisi, F., Nyasha, M., Muchadenyika, C., \& Faith, M.R. (2016). Effectiveness of Result Based Management as a Performance Management Tool Evidence from Small and Medium Enterprises (SMEs) in Zimbabwe. International Journal of Trend in Research 
and Development, Volume 3(1), 88-96. Retrieved from http://www.ijtrd.com/Papers.aspx? Id=11

Ndiwalana, J.K. (2009). Budgeting Participation, Goal Commitment and Employee Performance. Dissertation. Accounting and Finance Department of Makerene University Uganda.

Pratiwi, K., \& Himam, F. 2014. Kualitas Kehidupan Kerja Ditinjau dari Kepuasan Kerja dan Persepsi Terhadap Kinerja. Jurnal Psikologi Undip. 13(1). $42-49$. https://doi.org/10.14710/ipu.13.1.42-49

Pratolo, S., Sofyani, H., \& Anwar, M. (2020). Performance-based budgeting implementation in higer education institution: Determinants and impact on quality. Cogent Business \& Management. 7(1), 1-20. https://doi.org/10.1080/23311975.2020.1786315

Robbins, S. P., \& Judge, T. A. 2014. Perilaku Organisasi. Edisi 16. Jakarta: Salemba Empat

Safitri. (2019). Implementasi Manajemen Mutu Berbasis Madrasah di MTs Assalam Tanjung Sari Lampung Selatan. Skripsi. Universitas Islam Negeri Raden Intan Lampung.

Santosa, B. A. (2014). Sistem penganggaran pendidikan tinggi dari old public management menuju new public management. Jurnal Kependidikan, 2(2), 127-142. https://doi.org/https://doi.org/10.24090/jk.v2i2.556

Santos-Rodrigues, H., Faria, J., Cranfield, D., \& Morais, C. (2010). Intellectual Capital and Innovation: A Case Study of a Public Healthcare organisation in Europe. Electronic Journal of Knowledge Management. 11(4), 361-380. Retrieved from http:/ $/$ www.ejkm.com/issue/download.html?idArticle $=719$

Sholihah, R., Rosidi., \& Bambang, P. (2015). Pengaruh Kualitas Sumber Daya Manusia dan Komitmen Tujuan Terhadap Implementasi Anggaran Berbasis Kinerja dengan Budaya Organisasi sebagai Variabel Pemoderasi. El-Dinar: Jurnal Keuangan dan Perbankan Syariah. 3(1) 41-81. https://doi.org/10.18860/ed.v3i1.3338

Shore, L. \& Tetrick, L. (1991). A Construct Validity Study of the Survey of Perceived Organizational Support. Journal of Applied Psychology, 76(5), 637-643. https://doi.org/10.1037/0021-9010.76.5.637

Sofyani, H., \& Akbar, R. (2013). Hubungan faktor internal dan implementasi sistem akuntabilitas kinerja instansi pemerintah (SAKIP) di Pemerintah Daerah. Jumal Akuntansi dan Keuangan Indonesia, 10(2), 207-235. https://doi.org/10.21002/jaki.2013.10

Sofyani, H., Riyadh, H. A., \& Fahlevi, H. (2020). Improving service quality, accountability and transparency of local government: The intervening role of information technology governance. Bisnis \& Manajemen Cogent, 7(1), 1-20. https://doi.org/10.1080/23311975.2020.1735690

Spenser, L. M., \& Spenser, S. M. (1993). Competense at work models for superior performance. John wiley dan Sons Inc.

Sylvia, W. (2015). Factors Influencing the Implementation of Result Based Management in Governmental Organization: A Case of Ministry of Lands, Muranga County. Thesis Master. United States International University Africa. Retrieved from http://erepo.usiu.ac.ke/bitstream/handle/11732/2780/WAIRIMU\%20SYLVIA.pdf? sequence $=1$ \&is Allowed $=\mathrm{y}$

Try, D. (2008). "Mind the gap, please" Using public value theory to examine executive takeup of result-based management. International Journal of Productivity and Pervormance Management. 57(1), 22-36. https://doi.org/10.1108/17410400810841218

Tyler, T. R. (1987). Conditions leading to value-expressive effects in judgments of procedural justice: A test of four models. Journal of Personality and Social Psychology, 52(2), 333-344. https://doi.org/10.1037/0022-3514.52.2.333 
Pratolo, Mukti, \& Anwar

Result-based Management and Public Organizational Performance: ...

Upping, P. \& Oliver, J. (2012). Thai public universities: modernisation of accounting practices. Journal of Accounting \& Organizational Change, 8(3), 403-430. https://doi.org/10.1108/18325911211258362

Vnoučková, L., Urbancová, H., \& Smolová, H. (2018). Internal quality process management evaluation in higher education by students. DANUBE: Law, Economics and Social Issues Review, 9(2), 63-80. https://doi.org/10.2478/danb-2018-0005

Widyantoro. (2009). Implementasi Performance Based Budgeting sebuah Kajian Fenomenologis (Studi Kasus pada Universitas Diponegoro). Thesis. Program Pascasarjana Universitas Diponegoro Semarang.

Yusfaningrum, K. (2005). Analisis Pengaruh Partisipasi Anggaran terhadap Kinerja Manajerial melalui Komitmen Tujuan Anggaran dan Job Relevant Information (JRI) sebagai variabel intervening (Penelitian terhadap Perusahaan Manufaktur di Indonesia). Thesis. Program pascasarjana Universitas Diponegoro.

Yusof, J., Yaacob, H., \& Rahman, S. (2018). The Relationship of Workplace Spirituality on Organizational Citizenship Behaviour. Sains Humanika. 10(2), 31-39.

https://doi.org/10.11113/sh.v10n2.1399 